\title{
Branching, flowering and fruiting of Jatropha curcas treated with ethephon or benzyladenine and gibberellins
}

\author{
ANNE P. COSTA ${ }^{1}$, WAGNER VENDRAME ${ }^{1}$, SÍLVIA NIETSCHE ${ }^{2}$, JONATHAN \\ CRANE $^{1}$, KIMBERLY MOORE $^{3}$ and BRUCE SCHAFFER ${ }^{1}$ \\ ${ }^{1}$ Tropical Research and Education Center, University of Florida, 18905 SW 280 ${ }^{\text {th }}$ St., Homestead, FL, 33031-3314 USA \\ ${ }^{2}$ Departamento de Ciências Agrárias, Universidade Estadual de Montes Claros, \\ Av. Reinaldo Viana, 2630, 39440-000 Janaúba, MG, Brasil \\ ${ }^{3}$ Fort Lauderdale Research and Education Center, University of Florida, 3205 College Ave, Davie, FL, 33314-7799 USA
}

Manuscript received on November 24, 2014; accepted for publication on May 13, 2015

\begin{abstract}
Jatropha curcas L. has been identified for biofuel production but it presents limited commercial yields due to limited branching and a lack of yield uniformity. The objective of this study was to evaluate the effects of single application of ethephon or a combination of 6-benzyladenine (BA) with gibberellic acid isomers $\mathrm{A}_{4}$ and $\mathrm{A}_{7}\left(\mathrm{GA}_{4+7}\right)$ on branch induction, flowering and fruit production in jatropha plants with and without leaves. Plants with and without leaves showed differences for growth and reproductive variables. For all variables except inflorescence set, there were no significant statistical interactions between the presence of leaves and plant growth regulators concentration. The total number of flowers per inflorescence was reduced as ethephon concentration was increased. As BA $+\mathrm{GA}_{4+7}$ concentration increased, seed dry weight increased. Thus, ethephon and $\mathrm{BA}+\mathrm{GA}_{4+7}$ applications appeared to affect flowering and seed production to a greater extent than branching. The inability to discern significant treatment effects for most variables might have been due to the large variability within plant populations studied and thus resulting in an insufficient sample size. Therefore, data collected from this study were used for statistical estimations of sample sizes to provide a reference for future studies.
\end{abstract}

Key words: $\mathrm{BA}+\mathrm{GA}_{4+7}$, branching, ethephon, flowering, fruiting, jatropha.

\section{INTRODUCTION}

Jatropha (Jatropha curcas L.) is a pantropical species widely distributed in Central and South America that has been identified for biofuel production (Francis et al. 2005). The oil extracted from the seeds produces good quality biodiesel comparable with fossil diesel and biodiesel from other agronomic crops (Fairless 2007). Furthermore,

Correspondence to: Anne Pinheiro Costa

E-mail: annecosta@gmail.com the oil has been successfully tested for use as bio jet fuel, meeting European and American quality standards (Openshaw 2000).

Jatropha is still undomesticated and not considered a commercial crop due to the lack of breeding and genetic improvement, as well as the lack of specific cultivation practices (Francis et al. 2005). Most existing plantations were initiated from seeds derived from wild plants and therefore yields are variable (Carels 2009, Fairless 2007) and productivity is non-uniform (Kant and Wu 2011). 
Seed and oil yield in jatropha are affected by several factors, such as genetics (Das et al. 2010, Mohapatra and Panda 2010), age of the plant (Jongschaap et al. 2007), site characteristics such as rainfall, soil type and fertility (Francis et al. 2005), and agronomic practices such as plant spacing, pruning, irrigation, and fertilization (Behera et al. 2010, Gosh et al. 2011). Seed and oil production are also dependent on female flower production and seed set (Jongschaap et al. 2007). Therefore, a high male to female ratio is considered one of the factors limiting yield in this species (Wu et al. 2011). Because inflorescences are formed terminally on the branches, poor branching is considered a limitation to high yields (Carels 2009, Mohapatra and Panda 2010). Kureel (2006) reported that the overall oil yield could be improved by increasing the total number of fruit-bearing branches per plant.

Plant growth regulators (PGRs) have been used to modify plant architecture (Hayashi et al. 2001, Mackay et al. 2007). Exogenous applications of PGRs have been shown to induce growth responses resulting in increased growth and yield in a variety of crops including jatropha, Zea mays L. (corn), and Gossypium hirsutum L. (cotton) (Abdelgadir et al. 2010, Biles and Cothren 2001, Shekoofa and Emam 2008). Ethephon decomposes to ethylene within plant tissues and it is widely used as a plant growth regulator in commercial crop production. Ethephon is also used to reduce stem elongation, increase lateral branching, and manipulate flower initiation (Campos et al. 2009, Tamari e al. 1998). A combination of 6-benzyladenine (BA) with gibberellic acid isomers $\mathrm{A}_{4}$ and $\mathrm{A}_{7}\left(\mathrm{GA}_{4+7}\right)$ has been used to increase shoot elongation and flower production, as well as to release buds from apical dominance, promoting branch development (Jacyna and Puchala 2004, Keever and Foster 1990, Ravetta and Palzkill 1992).

Studies on the use of PGRs to induce branching and to improve yield in jatropha are limited. Increased branching in jatropha could increase fruit production. The objective of this study was to evaluate the effects of ethephon or BA $+\mathrm{GA}_{4+7}$ applications on branch induction, and subsequent flowering and fruit production in jatropha. The effects of PGRs on plants that were already actively growing and plants in a pre-leaf stage at the time of application were evaluated.

\section{MATERIALS AND METHODS}

\section{PLANT MATERIAL AND SITE CHARACTERISTICS}

Plants for the experiment were selected from a jatropha field plot at the University of Florida, Tropical Research and Educational Center (TREC) $\left(25^{\circ} 50^{\prime} \mathrm{N}\right.$ and $80^{\circ} 50^{\prime} \mathrm{W}, 3.8 \mathrm{~m}$ above sea level) in Homestead, FL.

Two-year-old plants were used for this study. Seeds originating from a jatropha accession from India were germinated in a greenhouse and planted in the field at TREC on June 25, 2009. Plants were spaced $2.4 \mathrm{~m}$ (within-row) by $3.7 \mathrm{~m}$ (between-rows). During prolonged dry periods, plants were irrigated every other day with a microsprinkler system (98 $\mathrm{L} \cdot \mathrm{h}^{-1}$ ) throughout the year. Plants were fertilized monthly with $100 \mathrm{~g}$ (July through December) to $200 \mathrm{~g}$ (January through April) of $6 \mathrm{~N}-5 \mathrm{P}_{2} \mathrm{O}_{5}-15 \mathrm{~K}_{2} \mathrm{O}$ fertilizer (Atlantic FEC - Fertilizer and Chemical Co., Homestead, FL).

At the initiation of treatments in May 2011, several plants had set leaves after breaking winter dormancy (plants with leaves) while others were at a pre-leaf stage (plants without leaves). A total of 64 plants were selected for the experiment; 32 with leaves and 32 without leaves. Plants were not pruned prior to or during the experiment.

PLANT GROWTH REGULATORS

Treatments consisted of foliar applications of ethephon (Florel ${ }^{\circledR}$; Monterey Lawn and Garden Products, Inc., Fresno, California, USA) or $\mathrm{BA}+\mathrm{GA}_{4+7}$ (Promalin $^{\circledR}$; Valent Biosciences ${ }^{\mathrm{TM}}$ Corporation, Walnut Creek, California, USA) to 
plants with leaves or without leaves. Ethephon was applied at concentrations of $0,500,1000$, or 2000 $\mathrm{mg} \cdot \mathrm{L}^{-1}$ and $\mathrm{BA}+\mathrm{GA}_{4+7}$ was applied at concentrations of $0,250,500$, or $1000 \mathrm{mgL}^{-1}$. Tween ${ }^{\circledR} 20$ (Merck, Germany) $0.1 \%(\mathrm{v} / \mathrm{v})$ was added to the solutions as a surfactant. The $\mathrm{pH}$ of ethephon and $\mathrm{BA}+\mathrm{GA}_{4+7}$ solutions were adjusted to 4.5 and 6.0, respectively, as recommended by the manufacturers. Plants (stem and canopy) were sprayed to run-off with $600 \mathrm{~mL}$ of solution per plant per application using a hand sprayer. Control plants were sprayed with $600 \mathrm{~mL}$ of tap water. Immediately after sunrise on May $27^{\text {th }}, 2011$, a single application of each PGR was made.

As per manufacturers' recommendations, ethephon and $\mathrm{BA}+\mathrm{GA}_{4+7}$ should be applied to actively growing plants. Plants with leaves were actively growing at the time of PGR applications, and had already started to flower and initiate fruit production. In contrast, plants "without leaves" had buds but they were at a pre-leaf stage at the time of PGR applications.

\section{MORPHOLOGICAL MEASUREMENTS}

Plants were monitored from May through November 2011. In November 2011, final plant size $(\mathrm{cm})$ and number of branches per plant were recorded. Plant height $(\mathrm{cm})$ was measured as the distance between soil surface and the tip of the main stem. Plant canopy area $(\mathrm{cm})$ was measured in two perpendicular directions (width1 and width2). Plant size $(\mathrm{cm})$ was calculated by (height + width1 + width2)/3, as suggested by Keever (1994). The number of all branches longer than $3 \mathrm{~cm}$ were recorded (Abdelgadir et al. 2010).

The total number of inflorescences per plant was recorded monthly. Inflorescence set was determined as the percentage of inflorescences with fruit per treatment. Number of flowers per inflorescence (total, male and female flowers), male to female flower ratio, number of fruit per bunch, and percentage of fruit set, were determined as the mean of 8 inflorescences randomly selected on each plant; a total of 32 inflorescences per treatment. Fruit set was determined as the percentage of fruit divided by the number of female flowers per inflorescence. Fruit set was estimated one month after the first inflorescence flower had opened. Total number of fruit per plant was recorded by harvesting and counting all fruit from inflorescences, formed after PGR application. Fruit were manually harvested when they started to mature. Total number of seeds per plant was recorded by manually opening all fruits from each plant and counting the number of seeds. Fruit yield (g) was recorded as the whole fruit fresh weight of all fruits harvested per plant. Seed yield (g) was recorded as the whole seed dry weight of all seeds harvested per plant, after seeds were oven dried for $48 \mathrm{~h}$ at $70{ }^{\circ} \mathrm{C}$. Fruit fresh weight $(\mathrm{g})$, number of seeds per fruit, seed fresh $(\mathrm{g})$ and dry weight $(\mathrm{g})$, and seed length $(\mathrm{mm})$, thickness $(\mathrm{mm})$ and width $(\mathrm{mm})$ were given as the mean of 50 fruit or seeds randomly selected per plant, a total of 200 fruit or seeds per treatment. To calculate 100 -seed weight (g), 100 seeds from each plant were randomly selected and weighed.

\section{EXPERIMENTAL DESIGN AND DATA ANALYSIS}

Data for each PGR (ethephon or BA $+\mathrm{GA}_{4+7}$ ) were analyzed separately. For each PGR, data were analyzed as a 2 (leaf presence or absence) by 4 (PGR concentration) factorial, with 4 single-plant replications per treatment combination, laid out in a completely randomized design. Two-way analysis of variance was performed to evaluate possible interactions between leaf presence and PGR concentrations. Regression analysis was performed to evaluate linear and quadratic responses of plant growth and development variables to PGR concentrations. Plants with and without leaves were combined for regression analysis for variables if no interaction between leaf presence and PGR concentration was detected. Differences 
between plants with leaves and without leaves were determined with a Student's T-test. Statistical analyses were performed using SAS Software (SAS Institute Inc., Cary, North Carolina, USA).

\section{RESULTS}

Within $4 \mathrm{~h}$ of ethephon and $\mathrm{BA}+\mathrm{GA}_{4+7}$ foliar applications, a light rain $(0.80 \mathrm{~mm})$ occurred at TREC, with a total of $15.8 \mathrm{~mm}$ for the day. Both ethephon and $\mathrm{BA}+\mathrm{GA}_{4+7}$ might have had their activity reduced due to rainfall within 6 to $24 \mathrm{~h}$ of application. Therefore plants were monitored daily to confirm any potential reduced activity of both PGRs. Plants sprayed with ethephon at 1000 or $2000 \mathrm{mg} \mathrm{L}^{-1}$ showed leaf, inflorescence, fruit yellowing, and leaf abscission beginning on the third day until the seventh day after application. Leaf burn was also observed for all ethephon concentrations. Plants sprayed with $\mathrm{BA}+\mathrm{GA}_{4+7}$ at 500 or $1000 \mathrm{mgL}^{-1}$ showed a slight leaf curling and leaf drop 4 days after application.

Plants with leaves were different from plants without leaves for several variables including plant size, number of fruit per plant, number of seeds per plant, fruit yield, seed yield, number of seeds per fruit, and inflorescence set (Tables SI and SII Supplementary Material). Except for inflorescence set, there was no interaction between leaf presence and PGR concentration. Therefore, for all variables except inflorescence set, data from plants with or without leaves were pooled for regression analysis, increasing sample size to 8 plants per treatment. Data on flowering was not collected for plants without leaves. We expected to see continuous flowering for both plants with and without leaves. However, flowering for plants without leaves was concentrated within the month of June and after that very few inflorescences were produced. Therefore, the numbers of inflorescences collected were not sufficient for statistical analysis and the data was not included.

Ethephon or $\mathrm{BA}+\mathrm{GA}_{4+7}$ applications at all concentrations tested, had no effect on the number of branches, inflorescences, fruits and seeds ( $\mathrm{P}>$ 0.05 ) (Tables SI and SII). However, for plants treated with ethephon, there was a linear response to PGR concentration for the number of flowers and for the number of male flowers per inflorescence. As ethephon concentration increased, there was a reduction in both the numbers of flowers and male flowers per inflorescence (Fig. 1, Table III). Flower variables were not affected by $\mathrm{BA}+\mathrm{GA}_{4+7}$ applications (Table III). Plants treated with $\mathrm{BA}+\mathrm{GA}_{4+7}$ showed a linear relationship between concentration and seed dry weight. As $\mathrm{BA}+\mathrm{GA}_{4+7}$ concentration increased, seed dry weight also increased, although with a low correlation coefficient $\left(\mathrm{R}^{2}=0.15\right)$ (Table SII).

\section{DISCUSSION}

Ethephon has been reported to promote yellowing and abscission in different plant parts (Crisosto et al. 1991, Trueman et al. 2002), similar to observations in this study at 1000 and $2000 \mathrm{mg} \mathrm{L}^{-1}$. High PGR concentrations or multiple PGR applications can result in phytotoxity symptoms such as leaf curling, leaf cupping, and discoloration (Oates et al. 2004). Leaf curling and leaf drop that were observed at 500 or $1000 \mathrm{mgL}^{-1}$ of $\mathrm{BA}+\mathrm{GA}_{4+7}$ could indicate phytotoxic effects at these concentrations. The presence of these symptoms indicates that the light rain which occurred within $4 \mathrm{~h}$ of PGR applications had no or little effect on the activity of either PGR, although a dilution effect caused by the rain cannot be discarded.

The number of male flowers per inflorescence decreased as ethephon concentration increased. This could explain why plants treated with ethephon showed a lower mean male to female flower ratio compared to plants treated with $\mathrm{BA}+$ $\mathrm{GA}_{4+7}$. Ethephon may have reduced the formation of flowers (Kher et al. 1974, Nagao and Sakai 1990) and/or increased the abortion of young flowers (Tamari et al. 1998). 

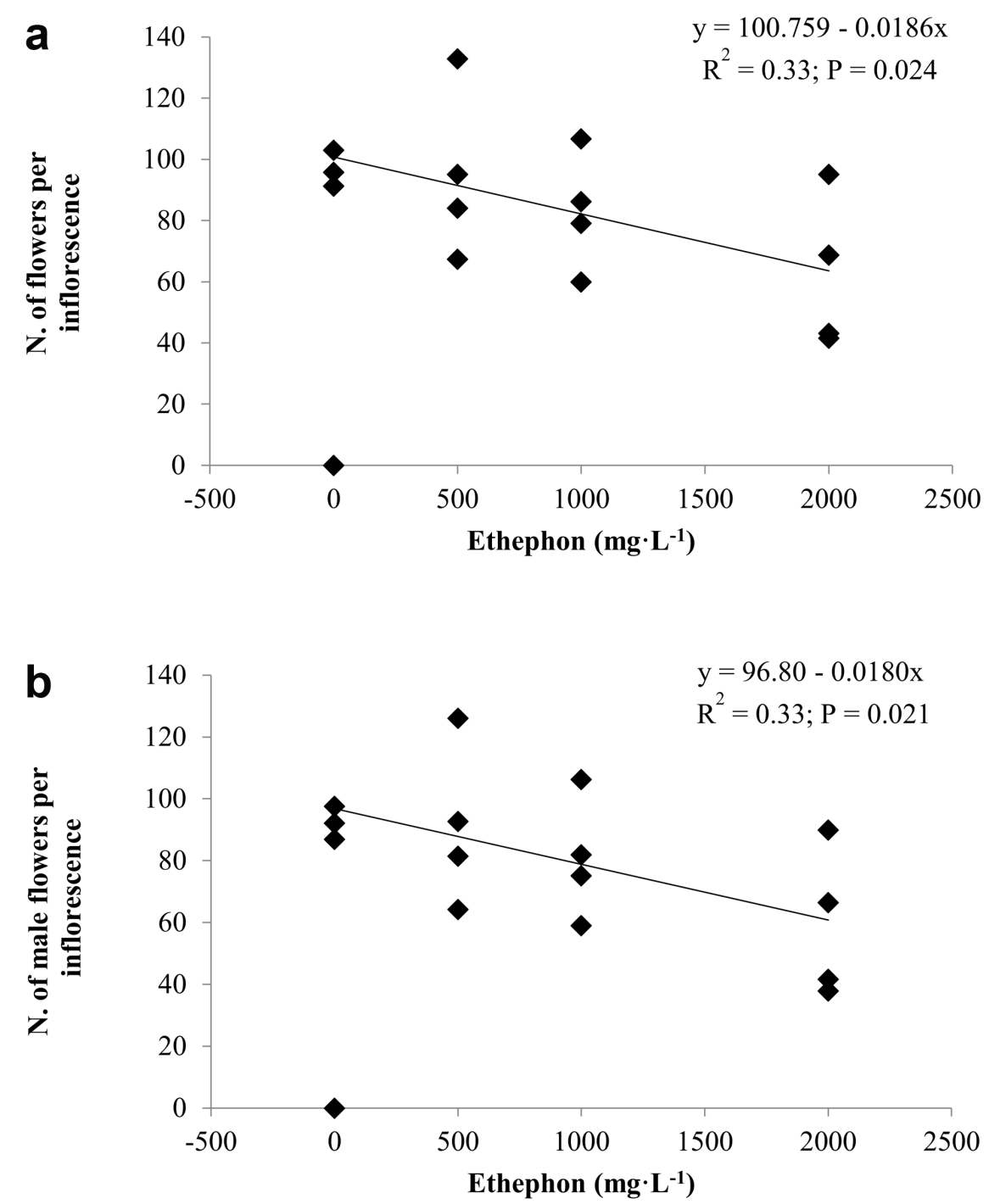

Figure 1 - Number of flowers per inflorescence (a) and number of male flowers per inflorescence (b) in Jatropha curcas L. plants treated with ethephon (Florel ${ }^{\circledR}$ ) at 0, 500, 1000 , or $2000 \mathrm{mg} \mathrm{L}^{-1}$. Plants were treated in May $2011(\mathrm{n}=4)$. Values are means of 8 inflorescences randomly selected for each plant, with a total of 32 inflorescences per treatment.

TABLE III

Effects of ethephon $\left(\right.$ Florel $\left.^{\circledR}\right)$ and BA $+\mathbf{G A}_{4+7}\left(\right.$ Promalin $\left.^{\circledR}\right)$ concentrations on flowering variables (mean \pm SD) of Jatropha curcas L. plants with leaves.

\begin{tabular}{|c|c|c|c|c|c|c|c|}
\hline & $\begin{array}{c}\text { PGR } \\
\left(\mathrm{mg} \cdot \mathrm{L}^{-1}\right)\end{array}$ & $\begin{array}{l}\text { N. flowers per } \\
\text { inflorescence }\end{array}$ & $\begin{array}{l}\text { N. female } \\
\text { flowers }\end{array}$ & N. male flowers & $\begin{array}{l}\text { Male to female } \\
\text { flower ratio }\end{array}$ & $\begin{array}{l}\text { N. fruit per } \\
\text { inflorescence }\end{array}$ & Fruit set (\%) \\
\hline \multirow{6}{*}{ 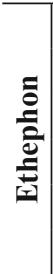 } & 0 & $96.70 \pm 5.90^{\dagger}$ & $4.47 \pm 0.90$ & $92.20 \pm 5.35$ & $21.17 \pm 3.76$ & $3.6 \pm 0.52$ & $81.17 \pm 8.37$ \\
\hline & 500 & $94.88 \pm 27.79$ & $3.73 \pm 2.07$ & $91.18 \pm 26.07$ & $27.35 \pm 9.52$ & $2.3 \pm 0.68$ & $67.10 \pm 17.02$ \\
\hline & 1000 & $83.05 \pm 19.34$ & $3.43 \pm 1.63$ & $80.58 \pm 19.66$ & $30.38 \pm 19.31$ & $2.48 \pm 1.32$ & $74.03 \pm 19.04$ \\
\hline & 2000 & $62.15 \pm 25.26$ & $3.23 \pm 1.68$ & $58.98 \pm 24.21$ & $21.15 \pm 9.20$ & $2.33 \pm 1.06$ & $74.28 \pm 6.96$ \\
\hline & $\mathrm{R}^{2}$ (linear) & $0.33^{\star}$ & NS & 0.33 & NS & NS & NS \\
\hline & $\mathrm{R}^{2}$ (quadratic) & NS & NS & NS & NS & NS & NS \\
\hline
\end{tabular}


TABLE III (continuation)

\begin{tabular}{|c|c|c|c|c|c|c|c|}
\hline & $\begin{array}{c}\text { PGR } \\
\left(\mathbf{m g} . \mathrm{L}^{-1}\right)\end{array}$ & $\begin{array}{l}\text { N. flowers per } \\
\text { inflorescence }\end{array}$ & $\begin{array}{l}\text { N. female } \\
\text { flowers }\end{array}$ & N. male flowers & $\begin{array}{l}\text { Male to female } \\
\text { flower ratio }\end{array}$ & $\begin{array}{l}\text { N. fruit per } \\
\text { inflorescence }\end{array}$ & Fruit set (\%) \\
\hline & 0 & $100.28 \pm 24.22^{\dagger}$ & $3.60 \pm 1.70$ & $96.68 \pm 24.87$ & $39.88 \pm 37.30$ & $2.75 \pm 1.49$ & $72.53 \pm 12.99$ \\
\hline f & 250 & $74.28 \pm 21.04$ & $1.50 \pm 0.45$ & $72.83 \pm 20.90$ & $53.58 \pm 23.54$ & $1.00 \pm 0.43$ & $68.75 \pm 20.70$ \\
\hline$\mho$ & 500 & $73.38 \pm 13.43$ & $2.60 \pm 1.56$ & $70.75 \pm 12.08$ & $32.53 \pm 12.86$ & $1.80 \pm 1.17$ & $66.40 \pm 21.07$ \\
\hline+ & 1000 & $93.83 \pm 4.18$ & $2.98 \pm 1.04$ & $90.85 \pm 3.77$ & $33.00 \pm 9.41$ & $2.18 \pm 0.57$ & $75.75 \pm 14.89$ \\
\hline$\infty$ & $\mathrm{R}^{2}$ (linear) & $\mathrm{NS}^{\ddagger}$ & NS & NS & NS & NS & NS \\
\hline & $\mathrm{R}^{2}$ (quadratic) & NS & NS & NS & NS & NS & NS \\
\hline
\end{tabular}

Mean of 8 inflorescences per plant.

${ }^{\ddagger}$ Coefficient of determination $\left(\mathrm{R}^{2}\right)$ for linear and quadratic responses to ethephon or BA $+\mathrm{GA}_{4+7}$ concentrations $(\mathrm{C})$ according to linear regression analysis. All $\mathrm{R}^{2}$ values were significant at $\mathrm{P}<0.05$, unless indicated by "NS".

The increase in seed dry weight as $\mathrm{BA}+\mathrm{GA}_{4+7}$ concentrations increased could be due to assimilate mobilization into the seeds caused by cytokinins and gibberellins (Brenner et al. 1989). Gibberellins have been shown to be related to early and late seed development and their concentration is usually correlated with seed fresh weight accumulation in different species (Pharis and King 1985). Similarly, BA is known for its ability to allocate nutrients to sites of application (Crosby et al. 1981). Increased seed dry weight due to $\mathrm{BA}+\mathrm{GA}_{4+7}$ application supports the hypothesis that gibberellins and cytokinins could play an important role on improving seed yield.

The lack of a branching response to PGR applications could be related to factors such as plant age, PGR concentrations, and the number of PGR applications. Effects on branching, plant height and number of inflorescences per plant have been shown to vary among several herbaceous species due to single and multiple ethephon applications at 500 or $1000 \mathrm{mg} \mathrm{L}^{-1}$ (Hayashi et al. 2001). Keever and Foster (1990) reported lack of branching response for several woody species when treated with single applications of BA at 125 to $1000 \mathrm{mgL}^{-1}$. Higher BA concentrations as well as $\mathrm{BA}+\mathrm{GA}_{4+7}$ at 2000 to $5000 \mathrm{mgL}^{-1}$ promoted greater numbers of shoots in most studied species. Single BA applications to 5-month-old and 1-year-old jatropha plants have been reported to promote branching both in greenhouse and field conditions at 2700 $m g \mathrm{~L}^{-1}$ (Abdelgadir et al. 2009). In the subsequent year, Abdelgadir et al. (2010) reported increasing numbers of flowers per plant, more fruits per bunch and heavier and bigger fruits for BA applications at 675,2025 , and $2700 \mathrm{mgL}^{-1}$, respectively. It is likely that the concentrations used in our study were not sufficiently high to promote branching and increased fruit production in 2-year-old jatropha plants, when applied as a single foliar treatment under South Florida environmental conditions. It is possible that repeated PGR applications might have resulted in more branching effects, as reported by Preece (1990) and Mackay et al. (2007).

The method of PGR application might also have affected the results of this study. BA applied directly to forming inflorescences was effective in inducing development of bisexual flowers, increasing the number of female flowers per inflorescence, and increasing seed yield (Pan and Xu 2010). PGR applied directly to forming inflorescences could have affected flower formation differently than PGR foliar application did.

The low response to PGR treatments could also be related to the genotype effect, i.e., an accession with plants in both pre-leaf and leaf stage at the time of PGR applications. Such genotype effect is probably responsible for the lack of significant treatment responses of most variables, although some trends were observed.

Due to the large variance observed within control plants, which could be greater than treatment effects, we decided to estimate sample sizes 
for specific variables using 16 control plants. Sample size estimate was calculated in order to access the projected sample size required to detect a 5 or $10 \%$ difference at $\mathrm{P}=0.05$. The sample size estimate was calculated as

$$
n=\frac{\left(Z_{\alpha}{ }^{2}\right)\left(v_{s}\right)}{\left(d^{2}\right)\left(\bar{x}^{2}\right)}
$$

where $\mathrm{n}$ is the required sample size, $\mathrm{Z}_{\alpha}$ is the value of the standardized normal variate corresponding to $\alpha, \mathrm{v}_{\mathrm{s}}$ is the sampling variance, $\bar{x}$ is the sample mean value, and $d$ is the margin of error expressed as a fraction of the plot mean (Gomez and Gomez 1984).

Adequate sample sizes are important to increase the probability of detecting statistically significant differences among treatment means. However, in horticultural experiments, field plots usually consist of limited number of plants. Sample size in this study was limited due to a limited number of plants in the field. In situations like this, inherent variability becomes an important factor to be considered (Batchelor and Reed 1918). As a consequence of genotypic variability within plants in this experiment, our results showed that the predicted sample sizes required for all variables evaluated, needed to be larger than those used in this study (Table IV).

As jatropha is a wild plant there is great variability within individuals. Although variability within jatropha plants has been reported in several studies (Mohapatra and Panda 2010, Das et al. 2010, Rao et al. 2008), there are no reports in literature about the extent in which sample size is affected by plant variability. This study consists on the first attempt to assess sample size in jatropha, based in plant inherent variability for plant growth, yield and yield components. Therefore, although sample sizes in the present study were probably too small to detect statistically significant differences, data collected provided useful information for future studies of PGR application effects on jatropha growth and development. In plant populations with very large inherent variability, the number

TABLE IV

Variability and sample size estimates for Jatropha curcas $\mathrm{L}$. accessions from India grown at the Tropical Research and Education Center (TREC) in Homestead, FL. Sample size estimation used a 5\% and $10 \%$ detectable difference at $P=$ 0.05. Values are mean, variance and sample size estimates, respectively, for 16 plants sprayed with water (control).

\begin{tabular}{|c|c|c|c|c|c|}
\hline & \multirow{2}{*}{ Mean } & \multirow{2}{*}{ Variance } & \multicolumn{3}{|c|}{ Sample size } \\
\hline & & & $5 \%$ & $10 \%$ & \\
\hline N. branches per plant & 75.86 & 483.13 & 128.97 & 32.24 & plants per treatment \\
\hline Plant size $(\mathrm{cm})$ & 254.47 & 902.59 & 21.42 & 5.35 & plants per treatment \\
\hline N. inflorescences per plant & 43.94 & 347.53 & 276.63 & 69.16 & plants per treatment \\
\hline N. fruit per plant & 75.25 & 2146.47 & 582.48 & 145.62 & plants per treatment \\
\hline Fruit fresh yield per plant $(\mathrm{g})$ & 961.51 & 253593.84 & 421.51 & 105.38 & plants per treatment \\
\hline N. seeds per plant & 206.44 & 15884.80 & 572.77 & 143.19 & plants per treatment \\
\hline Seed dry yield per plant (g) & 99.43 & 3809.91 & 592.18 & 148.04 & plants per treatment \\
\hline N. flowers per inflorescence ${ }^{\dagger}$ & 98.70 & 308.64 & 48.68 & 12.17 & inflorescences per plant \\
\hline N. female flowers per inflorescence ${ }^{\dagger}$ & 4.00 & 1.91 & 183.33 & 45.83 & inflorescences per plant \\
\hline N. male flowers per inflorescence ${ }^{\dagger}$ & 94.80 & 324.11 & 55.42 & 13.85 & inflorescences per plant \\
\hline Male to female flower ratio ${ }^{\dagger}$ & 31.80 & 800.91 & 1217.04 & 304.26 & inflorescences per plant \\
\hline Mean fruit fresh weight $(\mathrm{g})^{*}$ & 10.87 & 21.46 & 279.12 & 69.78 & fruit per plant \\
\hline Mean seed fresh weight $(\mathrm{g})^{\ddagger}$ & 0.86 & 0.13 & 288.17 & 72.04 & seeds per plant \\
\hline Mean seed dry weight $(\mathrm{g})^{\ddagger}$ & 0.44 & 0.03 & 302.03 & 75.51 & seeds per plant \\
\hline
\end{tabular}

${ }^{\dagger}$ Mean of 8 inflorescences per plant.

Mean of 50 fruit or seeds per plant. 
of samples required to detect significant treatment differences are often too great to be practical.

However, the number of samples required can be greatly reduced if the experiment is repeated over a number of years, and a yearly component is added to the statistical design and analysis (Schaffer and Baranowski 1986). Thus, we suggest that further experiments consider multiple year trials using a greater number of repetitions for field studies performed with jatropha plants originated from seeds. It is possible that a greater number of repetitions per treatment would have found a response to the ethephon and $\mathrm{BA}+\mathrm{GA}_{4+7}$ treatments on jatropha branching, flowering, and fruiting parameters.

\section{CONCLUSIONS}

This study represents the first assessment of the effects of ethephon and $\mathrm{BA}+\mathrm{GA}_{4+7}$ applications on branching in jatropha and provides invaluable information on sample size requirements on which to base future studies of the effects of foliar PGR applications on jatropha.

Ethephon and $\mathrm{BA}+\mathrm{GA}_{4+7}$ at the concentrations tested appeared to have a greater effect on flower and seed production than in branching stimulation. However, treatment effects may have been affected by dilution of PGR concentration and by genotype variability.

Further studies are necessary to clarify the responses of ethephon and $\mathrm{BA}+\mathrm{GA}_{4+7}$ applications in jatropha. Clonal material should be used to avoid the potential genetic variability. Single and multiple foliar applications, as well as higher product concentrations should also be considered. Product applications to forming inflorescences under South Florida conditions should also be included in future studies.

\section{ACKNOWLEDGMENTS}

We would like to thank Dr. James Colee of the University of Florida Statistics Department and M.Sc. Raoni Rosa Rodrigues for their helpful guidance with the statistical analyses. We would also like to thank Alba Myers and Maria Salinas for their technical assistance, and Regina Rieckenberg of Valent Biosciences Corporation ${ }^{\mathrm{TM}}$ for providing Promalin $^{\circledR}$ samples for this study. The authors thank the Florida Department of Agriculture and Consumer Services through the Farm to Fuel Grants Program, Vecenergy-The Vecellio Group, and the University of Florida for providing funding and support for this study.

\section{RESUMO}

Jatropha curcas L. tem sido identificada para a produção de biocombustível, mas apresenta produção comercial restrita devido à limitada ramificação e à ausência de uniformidade na produção. $\mathrm{O}$ objetivo deste estudo foi avaliar os efeitos de uma única aplicação de etefon ou da combinação de benziladenina (BA) com isômeros $\mathrm{A}_{4}$ e $\mathrm{A}_{7}$ do ácido giberélico $\left(\mathrm{GA}_{4+7}\right)$ na indução de ramificações, florescimento e frutificação, em plantas de jatropha com e sem folhas. Plantas com e sem folhas mostraram diferenças para variáveis de crescimento e reprodutivas. Não houve interação significativa entre a presença de folhas e as concentrações de regulador de crescimento, exceto para a variável vingamento de inflorescência. $\mathrm{O}$ número total de flores por inflorescência diminuiu à medida que a concentração de etefon aumentou. $\mathrm{O}$ peso seco da semente aumentou com o aumento da concentração de $\mathrm{BA}+\mathrm{GA}_{4+7}$. Assim, aplicações de etefon e $\mathrm{BA}+\mathrm{GA}_{4+7}$ pareceram ter um efeito mais pronunciado na produção de flores e sementes do que na indução de ramos. A inabilidade de discernir os efeitos significativos dos tratamentos para a maioria das variáveis pode ter ocorrido devido à grande variabilidade existente nas populações de plantas estudadas, resultando em um tamanho da amostra insuficiente. Portanto, os dados coletados neste estudo foram utilizados para estimativas estatísticas de tamanhos de amostras para fornecer referências a estudos futuros

Palavras-chave: $\mathrm{BA}+\mathrm{GA}_{4+7}$, ramificação, etefon, florescimento, frutificação, jatropha.

\section{REFERENCES}

ABDELGADIR HA, JAGER AK, JOHNSON SD AND VAN STADEN J. 2010. Influence of plant growth regulators 
on flowering, fruiting, seed oil content, and oil quality of Jatropha curcas. S Afr J Bot 76: 440-446.

ABDElgadir HA, JOHNSON SD AND VAN STADEN J. 2009. Promoting branching of a potential biofuel crop Jatropha curcas L. by foliar application of plant growth regulators. Plant Growth Regul 58: 287-295.

BATCHELOR LD AND REED HS. 1918. Relation of the variability of yields of fruit trees to the accuracy of field trials. J Agr Res 12: 245-283.

BEHERA SK, SRIVASTAVA P, TRIPATHI R, SINGH JP AND SINGH N. 2010. Evaluation of plant performance of Jatropha curcas L. under different agro-practices for optimizing biomass - A case study. Biomass Bioenerg 34: 30-41.

BILES SP AND COTHREN JT. 2001. Flowering and yield response of cotton to application of mepiquat chloride and PGR-IV. Crop Sci 41:1834-1837.

BRENNER ML, SCHREIBER BMN AND JONES RJ. 1989. Hormonal control of assimilate partitioning: regulation in the sink. Acta Hort 239: 141-148.

CAmpos MF, OnO EO AND Rodrigues JD. 2009. Desenvolvimento da parte aérea de plantas de soja em função de reguladores vegetais. Ceres 56: 74-79.

CARELS N. 2009. Chapter 2 Jatropha curcas: A Review. Adv Bot Res 50: 39-86.

CRisosto CH, TAusend PC, NAGaO MA, FuCHIGAMI LH AND CHEN THH. 1991. Effect of ethephon on ripening, seed development, branch growth and leaf abscission of Coffea arabica L. J Haw Pac Agri 3: 13-17.

Crosby KE, AUnG LH AND Buss GR. 1981. Influence of 6-Benzylaminopurine on fruit-set and seed development in two soybean, Glycine max (L.) Merr. genotypes. Plant Physiol 68: 985-988.

DAS S, MisRa RC, MAHAPATRA AK, GANTAYAT BP AND PATTNAIK RK. 2010. Genetic variability, character association and path analysis in Jatropha curcas. World Appl Sci J 8: 1304-1308.

FAIRLESS D. 2007. Biofuel: The little shrub that could maybe. Nature 449: 652-655.

FRANCIS G, EDINGER R AND BECKER K. 2005. A concept for simultaneous wasteland reclamation, fuel production, and socio-economic development in degraded areas in India: Need, potential and perspectives of Jatropha plantations. Nat Res Forum 29: 12-24.

GoMeZ KA AND GOMEZ AA. 1984. Statistical Procedures for Agricultural Research, $2^{\text {nd }}$ ed., New York: J Wiley \& Sons, USA, $680 \mathrm{p}$.

GOSH A, CHIKARA J AND CHAUDHARY DR. 2011. Diminution of economic yield as affected by pruning and chemical manipulation of Jatropha curcas L. Biomass Bioenerg 35: 1021-1029.

HAYASHI T, HEINS RD, CAMERON AC AND CARLSON WH. 2001. Ethephon influences flowering, height, and bran- ching of several herbaceous perennials. Sci Hortic 91: $305-$ 323.

HOPKINS WG AND HUNER NP. 2004. Introduction to Plant Physiology, $3^{\text {rd }}$ ed., New York: J Wiley \& Sons, USA, 560 p.

JACYNA T AND PUCHALA A. 2004. Application of environment friendly branch promoting substances to advance sweet cherry tree canopy development in the orchard. J Fruit Ornam Plant Res 12: 177-182.

JONGSCHAAP REE, CORRÉ WJ, BINDRABAN PS AND BRANDENBURG WA. 2007. Claims and facts on Jatropha curcas L. Global Jatropha curcas evaluation, breeding and propagation programme. Report 158. Wageningen: Plant Research International B. V., The Netherlands, 42 p.

KANT P AND WU S. 2011. The extraordinary collapse of Jatropha as a global biofuel. Environ Sci Technol 45: 71147115.

KEEVER GJ. 1994. BA-induced offset formation in hosta. J Environ Hort 13: 4-5.

KeEVER GJ AND Foster WJ. 1990. Chemically induced branching of woody landscape plants. J Environ Hort 8: 78-82.

KHER MA, YOKOI M AND KOSUGI K. 1974. Effects of ethrel on the growth and flower formation in pot chrysanthemums. J Jpn Soc Hort Sci 43: 91-96.

KUREEL RS. 2006. Prospects and potential of Jatropha curcas for biodiesel production. In: Biodiesel Conference towards Energy Independence - Focus on Jatropha, Hyderabad, India. Proceedings..., Hyderabad, p. 43-74.

MACKAY WA, ARNOLD MA, MCDONALD GV AND SANKHLA N. 2007. Cyclanilide alteration in growth of five landscape plant species during container production are location specific. J Environ Hort 25: 109-115.

MOHAPATRA S AND PANDA PK. 2010. Genetic variability on growth, phenological and seed characteristics of Jatropha curcas L. Not Sci Biol 2: 127-132.

NAGAO MA AND SAKAI WS. 1990. Effects of gibberellic acid, ethephon and girdling on the production of racemes in Macadamia integrifolia. Sci Hortic 42: 47-54.

OATES JM, KEEVER GJ AND KESSLER JR. 2004. BA-induced shoot formation in Indian Hawthorn. J Environ Hort 22: 71-74.

OPENSHAW K. 2000. A review of Jatropha curcas: an oil plant of unfulfilled promise. Biomass Bioenerg 19: 1-15.

PAN B AND XU Z. 2010. Benzyladenine treatment significantly increases the seed yield of the biofuel plant Jatropha curcas. J Plant Growth Regul 30: 166-174.

PHARIS RP AND KING RW. 1985. Gibberellins and reproductive development in seed plants. Ann Rev Plant Physiol 36: 517-568.

PREECE JE. 1990. Growth stimulation of Euphorbia lathyris L. by $\mathrm{GA}_{4+7}$ and BA. J Plant Growth Regul 9: 85-88.

RAO GR, KORWAR GR, SHANKER AK AND RAMAKRISHNA YS. 2008. Genetic associations, variability and diversity in 
seed characters, growth, reproductive phenology and yield in Jatropha curcas (L.) accessions. Trees-Struct Funct 22: 697-709.

RAVETTA DA AND PALZKILL DA. 1992. The effect of growth regulators and apex removal on branching and flower bud production of jojoba. Ind Crop Prod 1: 47-55.

SCHAFFER B AND BARANOWSKI RM. 1986. Sample size estimates for avocado yield experiments. J Amer Soc Hort Sci 111: 985-987.

SHEKOOFA A AND EMAM Y. 2008. Plant growth regulator (ethephon) alters maize (Zea mays L.) growth, water use and grain yield under water stress. J Agron 7: 41-48.

TAMARI G, PAPPA L, ZERED T AND BOROCHOV A. 1998. Effects of ethrel and gibberellin on impatiens plants. Sci Hortic 76: 29-35.

Trueman SJ, MCCONCHIE CA AND TURnBUlL CGN. 2002. Ethephon promotion of crop abscission for unshaken and mechanically shaken macadamia. Aust J Exp Agr 42: 1001-1008.

WU J, LIU Y, TANG L, ZHANG F AND CHEN F. 2011. A study on structural features in early flower development of Jatropha curcas L. and the classification of its inflorescences. Afr J Agr Res 6: 275-284.

\section{SUPPLEMENTARY MATERIAL}

TABLE SI - Effects of ethephon (Florel ${ }^{\circledR}$ ) concentrations on growth and reproductive variables (mean $\pm \mathrm{SD}$ ) of Jatropha curcas L. plants with leaves and plants without leaves. ${ }^{\dagger}$ Test of statistical interactions between ethephon concentrations (C) and leaves (L) for each plant variable according to a two-way
ANOVA. NS $=$ non-significant, $*=\mathrm{P} \leq 0.05$ and $* *=\mathrm{P} \leq 0.01$ ${ }^{*}$ Mean comparison between plants with (Yes) and without (No) leaves at each ethephon concentrations according to a nonpaired T-test $(\mathrm{n}=4)$. NS indicates non-significant, * indicates $\mathrm{P}$ $\leq 0.05$, ** indicates $\mathrm{P} \leq 0.01$, and $* * *=\mathrm{P} \leq 0.001$. ${ }^{\S}$ Coefficient of determination $\left(\mathrm{R}^{2}\right)$ for linear and quadratic responses to ethephon concentrations (C) according to linear regression analysis. Treatments with (Yes) and without (No) leaves were pooled for regression analyses because there was no significant interaction $(\mathrm{P}>0.05)$ between ethephon concentrations and leaves. All $\mathrm{R}^{2}$ values were significant at $\mathrm{P}<0.05$, unless indicated by "NS". "Mean of 50 fruit or seeds per plant.

TABLE SII - Effects of BA $+\mathrm{GA}_{4+7}\left(\right.$ Promalin $\left.^{\circledR}\right)$ concentrations on growth and reproductive variables (mean $\pm \mathrm{SD}$ ) of Jatropha curcas L. plants with leaves or without leaves. 'Test of statistical interactions between $\mathrm{BA}+\mathrm{GA}_{4+7}$ concentrations $(\mathrm{C})$ and leaves (L) for each plant variable according to a two-way ANOVA. NS $=$ non-significant, $*=\mathrm{P} \leq 0.05$ and $* *=\mathrm{P} \leq 0.01$. ${ }^{\star}$ Mean comparison between plants with (Yes) and without (No) leaves at each $\mathrm{BA}+\mathrm{GA}_{4+7}$ concentrations according to a nonpaired T-test $(\mathrm{n}=4)$. NS indicates non-significant, * indicates $\mathrm{P} \leq 0.05, * *$ indicates $\mathrm{P} \leq 0.01$, and $* * * \mathrm{P} \leq 0.001 .{ }^{\S}$ Coefficient of determination $\left(\mathrm{R}^{2}\right)$ for linear and quadratic responses to $\mathrm{BA}+\mathrm{GA}_{4+7}$ concentrations $(\mathrm{C})$ according to linear regression analysis. Treatments with (Yes) and without (No) leaves were pooled for regression analyses when no significant interaction $(\mathrm{P}>0.05)$ was found between $\mathrm{BA}+\mathrm{GA}_{4+7}$ concentrations and leaves. All $\mathrm{R}^{2}$ values were significant at $\mathrm{P}<0.05$, unless indicated by "NS". All $\mathrm{R}^{2}$ values were significant at $\mathrm{P}<0.05$, unless indicated by "NS". "Mean of 50 fruit or seeds per plant. 